\title{
IAMJ
}

INTERNATIONAL

AYURVEDIC

MEDICAL JOURNAL

\section{A LONGITUDINAL OBSERVATIONAL STUDY ON THE EFFECT OF GAURASARSAPA LEPANA AND LAKSHADI TAILA GANDUSHA IN DIABETIC PERIODONTITIS}

\author{
Chaya. C', Suja K sreedhar ${ }^{2}$ \\ ${ }^{1}$ Assistant Professor, Dept of Shalakyatantra, JSS Ayurveda Medical College, Mysuru, Karnataka, India \\ ${ }^{2}$ Former H.O.D, Dept of Shalakyatantra, GAMC, Bengaluru, Karnataka, India
}

Corresponding Author: chayaambika@gmail.com

https://doi.org/10.46607/iamj0509082021

(Published Online: August 2021)

Open Access

(C) International Ayurvedic Medical Journal, India 2021

Article Received:09/07//2021 - Peer Reviewed:14/07/2021 - Accepted for Publication:15/07/2021

Check for updates

\begin{abstract}
Diabetes and Periodontitis are the most common chronic disease in the world. Abundant epidemiology evidence implies a bidirectional relationship between these two diseases. Periodontitis has been reported as the 6th complication of Diabetic Mellitus. In Ayurveda, there is no direct reference for Diabetic Periodontitis. But the symptoms of Upakusha can be correlated to Periodontitis. Dantamala is one of the Prameha Poorvarupa which is quoted by Sushruta in NidanaSthana. Prathisarana and Gandusha are the procedures explained in our classics for oral hygiene. So, the present study was undertaken to study the effect of Gaurasarsapa Lepana and LakshadiTaila Gandusha in the management of Diabetic Periodontitis. 40 patients with Diabetic Periodontitis as per inclusion criteria were selected from O.P.D and IPD of SJIIM Hospital, Bengaluru.40 Patients were treated by Gaurasarsapa Lepana followed by LakshadiTaila Gandusha for 15dyas. Clinical signs and symptoms were given suitable scores according to the severity and were assessed by pre and post data given in research proforma, designed for the study. The treatment showed significant results after the treatment.
\end{abstract}

Keywords: Diabetic Periodontitis, Upakusha, Prathisarana, Gandusha. 


\section{INTRODUCTION}

Ayurveda is one of the oldest sciences in the world with a long record of clinical experience. It is not only science but philosophy also. The main Aim of the Ayurveda is to attain Dharma, Artha, Kama and Moksha by health. Ill health takes away the health and happiness from life ${ }^{1}$. Shalakya tantra is one of the important branches of Ashtanga Ayurveda, which deals with Urdwajatrugata Rogas. The Mukha i.e. oral cavity works as a reflector of the body health by acting as gateway of the alimentary canal and it is considered to be one of the most important parts of the Urdhwa Jatru. Upakusha is one among the Dantamoolagatha Rogas mentioned under Mukha rogas. The reference is available in Sushruta Samhitha (2350B.C). Clinical features are inflamed gums which Bleed on brushing, burning sensation, Halitosis and Tooth mobility due to the vitiation of Pitta and Raktha. Clinically Upakusha shows similarity with chronic Periodontitis. Periodontitis is defined as "an inflammatory disease of the supporting tissues of the teeth caused by specific microorganisms, resulting in progressive destruction of periodontal ligament and alveolar bone with increased probing depth formation, recession or both". The diseases cause mental distress to the person mainly due to Foul smell, Pus discharge, Gingival bleeding and Tooth mobility". It is more often caused by dental plaque. Diabetes and Periodontitis are common chronic diseases in the world and abundant epidemiology evidence implies a bidirectional relationship between these 2 diseases. Periodontitis has been reported as the 6th complication of Diabetic Mellitus ${ }^{2}$. People with diabetes are more likely to have periodontal disease than people without diabetes, probably because people with diabetes are more susceptible to contracting infections. Periodontal disease is often considered a complication of Diabetes. Those people who don't have their diabetes under control are especially at risk.

Periodontal disease is prevalent both in developed and developing countries and in India incidence rate is $100 \%$. Type 2 Diabetic individuals with a severe form of periodontal disease have a 3.2 times greater mortality risk. Untreated chronic Periodontitis is responsible for tooth loss in the majority of cases. This study is targeted in managing Periodontitis while giving importance to maintaining better glycemic control.In Ayurveda, there is no direct reference for Diabetic Periodontitis. But the symptoms explained are correlated with Upakusha. (Symptoms are Danthaveshteshu Daha, Paka, Chaladanta, Raktha srava, Pootimuka). Dantamala is one of the Prameha Poorvarupa which is quoted by Sushruta in NidanaSthana. ${ }^{3}$ Gandusha and Lepana are proved to be effective in Mukha roga and its complication. They are cost-effective since no major infrastructure is required, less intervention in manual support, adaptable at home/clinical level.

Gaurasarsapa Lepa ${ }^{4}$ consist of Gaurasarsapa choorna and Lakshadi Taila Gandusha consist of Tilataila, Laksharasa, Kshira, Lodra, Katphala, Manjista, Padmaka, Padmakesara, Raktha chandana, Neelothpahala and Yatimadhu. Hence in the present study, an effort is made to observe the effect of Gaurasarsapa Lepana and Gandusha through Lakshadi Taila in Diabetic Periodontitis. The ingredients of the preparations are easily available, cost-effective, easy to prepare and administer. Considering the above factors, this study has been taken up to evaluate its efficacy in the management of Upakusha.

\section{MATERIALS AND METHODS}

Drug preparation ${ }^{5}$ Lakshadi Taila and Gaurasarsapa choorna: The Taila and choorna are prepared as per Taila Paka Vidhi and panchavida Kashaya Kalpana Adhyaya respectively explained in Sharangadhara Samhita at Dept of Rasashastra and Bhaishajya Kalpana, Government Ayurvedic Medical College, Bengaluru.

Laksha rasa preparation -One part of dried Laksha (500grams) boiled with eight-part of water (4000 litres) up to one fourth. Then it filtered at 21 times. Finally, we get 1liter of Laksha rasa.

Taila preparation - The fine powder of the above drugs (Kalka dravya) was prepared and mixed with water to make Kalka. Tila Taila was taken in a steel vessel, to it prepared Laksha rasa, ksheera and Kalka 
were added mixed thoroughly and heated over Mandagni till it attained Madhyama paka. It was filtered through a clean cloth. After cooling the prepared medicine was kept in a clean vessel.

2. Gaurasarsapa preparation -Seeds of Gaurasarsapa were made fine powder with help of kalwa yantra

Table 1: (Lakshadi Taila parameter)

\begin{tabular}{|l|l|}
\hline Parameters & LAKSHADI TAILA \\
\hline Loss On Drying & 0.1963 \\
\hline Acid Value & 0.6645 \\
\hline Saponification Test & 202.4962 \\
\hline Specific Gravity & 0.917 \\
\hline Iodine Value & 96.465 \\
\hline Refractive Index & 1.472 \\
\hline Rancidity & ABSENT \\
\hline Peroxide Value & ABSENT \\
\hline
\end{tabular}

Table 2: (Gaurasarsapa choorna parameter)

\begin{tabular}{|l|l|}
\hline Parameters & Gaurasarsapa Choorna \\
\hline Foreign Matter & $1.2 \%$ \\
\hline Total Ash & $2.95 \%$ \\
\hline Acid-Insoluble Ash & $0.32 \%$ \\
\hline Alcohol-Soluble & $0.917 \%$ \\
\hline Extractive & \\
\hline Water-Soluble & $18.59 \%$ \\
\hline Extractive & \\
\hline Fixed Oil & $37 \%$ \\
\hline
\end{tabular}
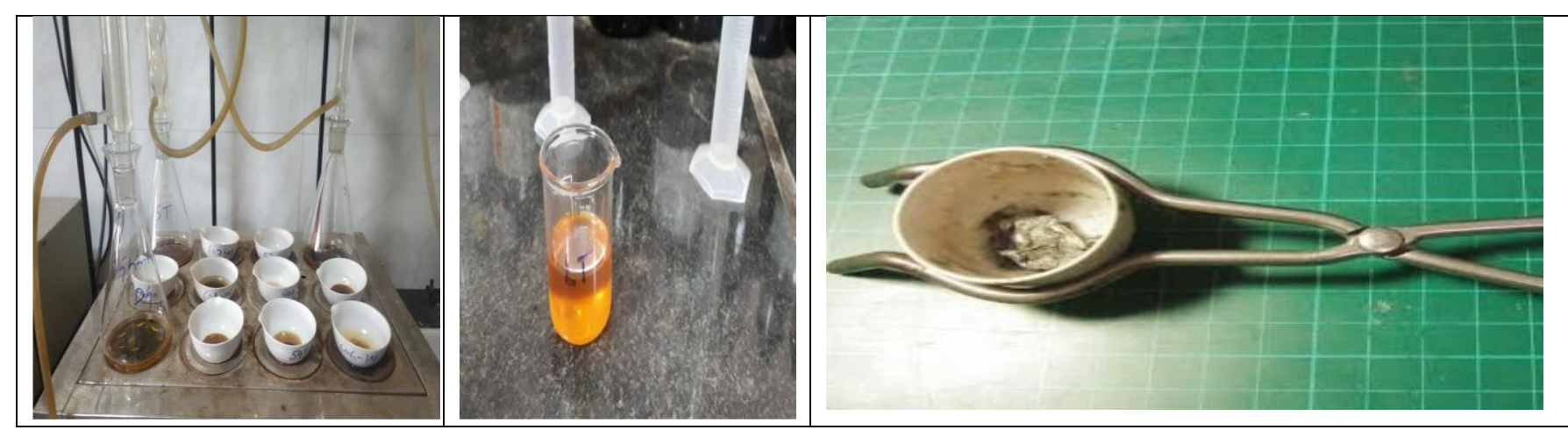

Figure 1: (Phytochemical Analysis of Lakshadi Taila),

Figure 2: (Phytochemical Analysis of Gaurasarsapa Choorna) 
Patient selection- The patient attending the OP and IP. P.G. unit of Shalakya tantra Department, Sri Jayachamarajendra Institute of Indian Medicine, Bengaluru

\section{Statistical Analysis}

The data was collected $\&$ analyzed. The total scores before \& after treatment were assessed statistically using the Wilcoxon $\mathbf{Z}$ test. Analysis was considered by SPSS for Windows (Statistical presentation system software).

\section{Study Design}

1. Longitudinal observational study.

2. Total of 40 patients will be selected for the study. These patients will be advised not to withdraw from regular diabetic medication and monitored regularly for good glycemic control

Table 3: Study Design

\begin{tabular}{|l|l|l|l|l|l|l|l|}
\hline $\begin{array}{l}\text { Showing } \\
\text { study } \\
\text { design }\end{array}$ & Chikitsa & Prayogakala & Duration & Dose & Follow-up & $\begin{array}{l}\text { Total } \\
\text { treatment } \\
\text { period }\end{array}$ \\
\hline $\begin{array}{l}\text { Single } \\
\text { group }\end{array}$ & $\begin{array}{l}\text { 1.Gaurasarsapalepana } \\
\text { Followed by } \\
\text { 2.Lakshadi taila }\end{array}$ & $\begin{array}{l}\text { Morning and } \\
\text { Evening } \\
\text { Morning and } \\
\text { Evening }\end{array}$ & $\begin{array}{l}\text { 15 days. } \\
\text { 15days }\end{array}$ & $\begin{array}{l}\text { Sufficient } \\
\text { quantity } \\
\text { Sufficient } \\
\text { quantity }\end{array}$ & $\begin{array}{l}\text { 1 week after 15 } \\
\text { days treatment } \\
1 \text { week after 15 } \\
\text { days of } \\
\text { treatment }\end{array}$ & \\
\hline
\end{tabular}

\section{Method of collection of data}

1. Sampling method: Simple Random Sampling (SRS)

2. Sample size: 40 subjects irrespective of gender, socio-economic status, religion, were selected for the study.

3. Selection criteria: Based on diagnostic criteria and inclusion criteria.

\section{Inclusion Criteria:}

1. Type 2 Diabetic Mellitus.

2. Subjects with good glycemic control (HbA1c investigation).

3. Subjects with Diabetic Periodontitis signs and symptoms.

\section{Exclusion Criteria:}

1. Juvenile Diabetes.

2. Periodontitis having neoplasia.

3. Patients on dentures.

4. Hemorrhagic disorder.

5. Immune deficiency disorders like HIV.

6. Pregnant and lactating women.

Investigations:

1. BT and CT.

2. HbA1c.

\section{Assessment Criteria:}

Subjective Parameters - seven subjective parameters as per Ayurveda features have been evaluated before and after the treatment by using a 0-3 scoring system.

Objective Parameters - Gingival Index, calculus index, halitosis index, mobility index and periodontal index

Instructions to the Patient -All the patients were advised to follow the instructions during therapy and in the follow-up period.

- Oral hygienic practices and their importance in the reversal of the disease were explained.

- Proper brushing by using medium bristle brush 2times a day morning and evening after meals.

- Instructions regarding Ahara (food) and Vihara (regimen) were given i.e. fibrous, non-sticky; less sweeten etc. and proper mastication by using both sides of the jaws.

- Proper mouth rinses after each meal/food item.

\section{Method of Prathisarana:}

- Patients were advised to do Prathisarana 2 times morning and evening after proper cleaning of the mouth.

- Gaurasarsapa Choorna should be taken in sufficient quantity and mixed with a very little 
amount of lukewarm water and make the Choorna into paste form.

- It should be taken on tip of the index finger and applied all over the gum smoothly with gentle pressure for 3-5 min in a clockwise direction.

- Finally with slight pressure massage toward the gingival margin should be done and the drug should remain on the gum for 5 minutes. After that advice gargling with hot water.

\section{Methods of Gandusha}

The patient should be made to sit comfortably in a straight position. Then take the medicated liquid in his mouth without doing any movement inside with a concentrated mind and face slightly lifted. Then advised not to drink the liquid and hold it until the mouth gets filled with oropharyngeal secretions and watery discharge appears from the nose and the eyes (Netra). Then it should be spit out and relaxed.

Data Analysis: Data was recorded in pre, posttreatment and follow up periods. Data analysis was carried out by using the SPSS statistics 16 packages. Distribution was generated and data were tabulated.

\section{Observation and result}

The maximum number of the patients i.e. $57.5 \%$ reported in the age group of 50-60 years. The majority of the patients $(72.5 \%)$ were males. Also, $37.5 \%$ of the patients were employees, and the majority of the patients $(52.5 \%)$ belonged to the middle class. $100 \%$ of patients were having complaints of Shotha, dhourgandhya, gingival index, halitosis index and periodontal index. $97.5 \%$ of patients were having complaints of chaladantha, tooth mobility index and Danta Shoola. daha was present in $85 \%$ of patients and $52.5 \%$ of patients were reported to have paka. Rakthasrava was reported in $95 \%$ of patients and calculus index was found in $87.5 \%$ of patients. In the present study, 40 patients having Diabetic Periodontitis fulfilling the inclusion criteria were randomly selected. Each patient was observed thoroughly and noted. The observations were recorded, and necessary charts and graphs are made.

Effect on Daha: Statistical analysis showed that the mean score which was 1.63 before treatment was reduced to 0.38 after treatment with $76.92 \%$ improve- ment, and there is a statistically significant change. $(\mathrm{P}<0.05)$

Effect on Paka: Statistical analysis showed that the mean score which was 0.65 before treatment was reduced to 0.10 after treatment with $84.62 \%$ improvement, and there is a statistically significant change. $(\mathrm{P}<0.05)$

Effect on Rakthasrava: Statistical analysis showed that the mean score which was 1.50 before treatment, was reduced to 0.45 after treatment with $70 \%$ improvement, and there is a statistically significant change. $(\mathrm{P}<0.05)$

Effect on Chaladanta: Statistical analysis showed that the mean score which was 1.65 before treatment, was reduced to 0.63 after treatment with $62.12 \%$ improvement, and there is a statistically significant change. $(\mathrm{P}<0.05)$

Effect on Danta Shoola: Statistical analysis showed that the mean score which was 1.80 before treatment was reduced to 0.38 after treatment with $79.17 \%$ improvement, and there is a statistically significant change. $(\mathrm{P}<0.05)$

Effect on Shotha: Statistical analysis showed that the mean score which was 1.60 before treatment was reduced to 0.35 after treatment with $78.13 \%$ improvement, and there is a statistically significant change. $(\mathrm{P}<0.05)$

Effect on Dourgandhhya: Statistical analysis showed that the mean score which was 2.23 before treatment was reduced to 1.90 after treatment with $85.39 \%$ improvement, and there is a statistically significant change. $(\mathrm{P}<0.05)$

Effect on Calculus Index: Statistical analysis showed that the mean score which was 1.35 before treatment was reduced to 0.45 after treatment with $66.67 \%$ improvement, and there is a statistically significant change. $(\mathrm{P}<0.05)$

Effect on Halitosis Index: Statistical analysis showed that the mean score which was 2.23 before treatment was reduced to 0.33 after treatment with $85.39 \%$ improvement, and there is a statistically significant change. $(\mathrm{P}<0.05)$

Effect on Tooth Mobility: Statistical analysis showed that the mean score which was 1.65 before 
treatment was reduced to 0.62 after treatment with $65.12 \%$ improvement, and there is a statistically significant change. $(\mathrm{P}<0.05)$

Effect on Gingival Index: Statistical analysis showed that the mean score which was 1.60 before treatment was reduced to 0.35 after treatment with $78.13 \%$ improvement, and there is a statistically significant change. $(\mathrm{P}<0.05)$

Effect on Periodontal Index: Statistical analysis showed that the mean score which was 2.33 before

Figure 3: Case of diabetic Periodontitis

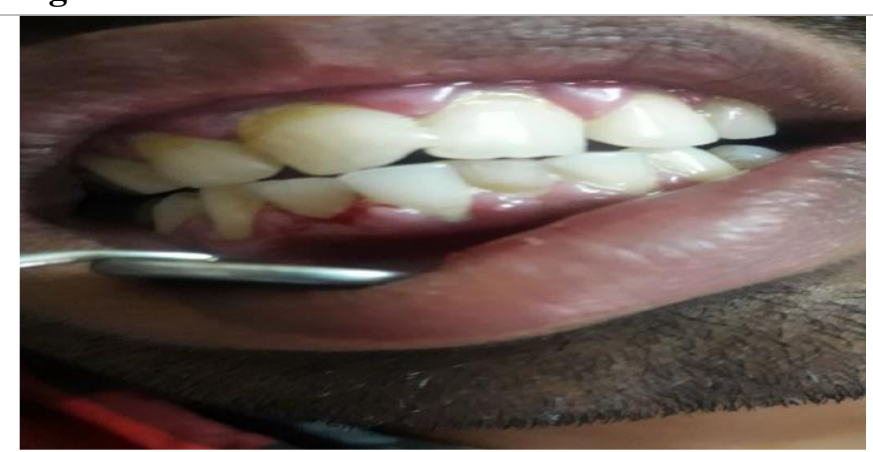

Before treatment treatment was reduced to 1.00 after treatment with $56.99 \%$ improvement, and there is a statistically significant change. $(\mathrm{P}<0.05)$

In Overall effect of treatment in Diabetic Periodontitis out of 40 patients in this study-1 patient $(2 \%)$ was getting Mild improvement, 15 patients (38\%) were getting Moderate improvement and 24 patients $(60 \%)$ were getting Marked Improvement.

The overall effect of the treatment is $76.86 \%$.

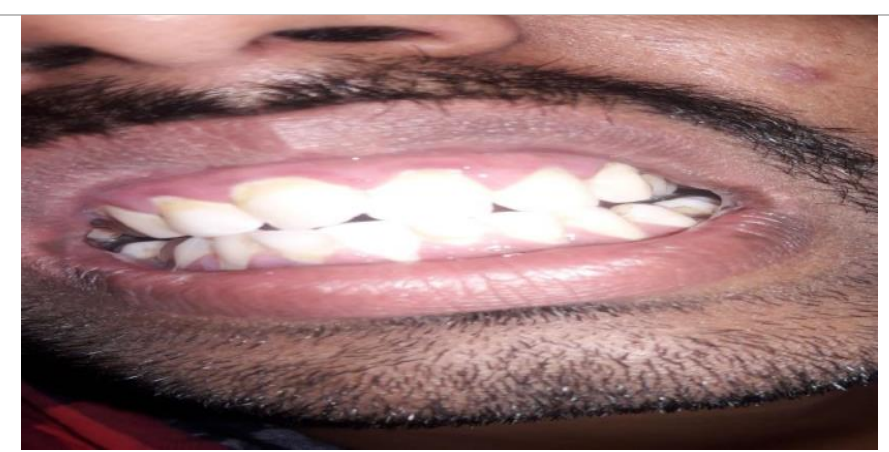

After treatment

Figure 4: (overall effect of treatment)

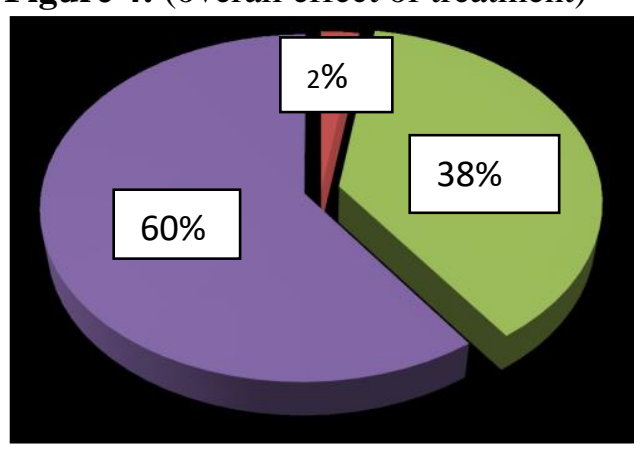

\section{DISCUSSION}

Diabetes and Periodontal disease are highly prevalent in India. The prevalence rate in India is $42.8 \%$. This is due to a lack of education about dental hygiene among the public. Frequent intake of sweets, improper brushing of teeth, tobacco chewing, taking nonveg and junk food leads to poor dental hygiene. People ignore periodontal diseases as they are never lifethreatening. It has been observed that the incidence of Diabetic Periodontitis is maximum in the age group of 50-60, subsequently in the age group of 40-50.
0\%-No improvement

$2 \%$-mild improvement

38\%-moderate improvement

$60 \%$-marked improvement 
cine, which in turn gives strength to the roots of the teeth. The drugs used in this preparation Possess Anti-inflammatory, Anti-infective property and Antioxidant property helps in faster healing. Due to the lipophilic action of Taila is best for absorption of the drug.

Gandusha with Taila forms a smear layer over the dentin thus helps in curing hypersensitivity. Oil pulling activates salivary enzymes to absorb toxins such as chemical toxins, bacterial toxins and environmental toxins from the blood and removed them from the body through the tongue. It generates Antioxidants that damage the cell wall of microorganisms and kill them. This oil will coat the teeth and gingival and inhibits bacterial co-aggregation and plaque formation. Thus, the plaque building bacteria responsible for dental caries, gingivitis, periodontitis and bad breath from the mouth are removed from the oral cavity. Gums become pink, healthier and the problem of bleeding gums is solved. Oil pulling is observed to bring improvement in oral hygiene when practised properly and regularly.

Gaurasarsapa Choorna - has-Katu, Thiktha Rasa, Ushna Virya and Katu Vipaka; Vatahara, Kaphahara. Kanduhara, Krimihara and Shoolahara properties. Tikta Rasa is Having Kaphahara, Pittahra, Dahahara, Krimihara, Lekhana and Raktha Shodhaka Properties. Katu Rasa is having the property of Vrana Ropaka. Ushna Veerya is Kapha Shamaka. Ultimately used in Mukha Roga. It contains vit k; usually, vit $\mathrm{k}$ is useful in bleeding disorders so it is helpful in the treatment of bleeding gum. It shows activities like Anti-microbial, Anti-Anthelmintic, Analgesic, Antiinflammatory, Anti-pyretic.

Lakshadi taila helps to reduce the inflammation of gum, bleeding, pain and discolouration of gums. Kashaya and thiktha rasa of lakshadi taila help to pacify Pittha and Kapha Dosha. It is antiinflammatory, Antibacterial and Haemostatic. Also have Vrana Shodhaka, Vrana Ropaka and Krimighna properties. Laksha is one of AsthiSandaneeyadravya, so it is helpful in Sandana of Periodontal bone and ligaments.
Hence all these drugs help in reducing the inflammation of the Gingival, prevent the growth of microorganisms, helps in faster healing and restore the integrity of the Periodontal tissues.

Thus, the combination of Prathisarana with Gaura sarsapa Lepa and Gandusha with Lakshadi Taila is beneficial in Diabetic Periodontitis.

\section{CONCLUSION}

The main cause of the disease Upakusha is poor oral hygiene. Both Prathisarana and Gandusha has shown significant result in Diabetic Periodontitis. Prathisarana and Gandusha have a remarkable effect on the management of Upakusha. The drug in the lakshadi taila has significant Anti-microbial activity, Anti-inflammatory, Antioxidant, Sandaneeya, Rakthasthambhaka, Vrana Shodhaka and Vrana-ropaka action. Gaurasarsapa choorna have significant Antimicrobial, Anthelmintic, Analgesic, Antiinflammatory properties and contains vit $\mathrm{K}$, so it helps in blood coagulation (Raktha sthambaka).

Observation of Pathya and Apathya during and after treatment is very important in preventing the recurrence of the disease.

\section{REFERENCES}

1. Acharya Yadavji Trikamji Acharya, Charaka Samhita of Agnivesha, Chakrapani Datta's, Ayurveda deepika sutrasthana, 1/15, Reprint ed. Chaukhambha Samskrit Sansthan: Varanasi, 2004, pp.06

2. Research article - The two-way relationship between diabetes and periodontal disease. (This is the third in a series of research articles delivered at the RCDSO symposium, oral health; A window to systemic disease, on February 4, 2005)

3. P V. Sharma, Sushrutha Samhita English translation Nidanasthana, Prameha Nidana Vol 2, chapter 6, shloka 4. Varanasi; Chaukhambhaorientalia.Varanasi; 2000. Page no 45.

4. Srimadvaidyashodala Gadanigraha truthiya shalakyadi panchakarmadhikarantho bhagha, Mukharoga adhyaya 5/67. Chaukambara Samskrutha Samsthana. Varanasi; 1990.Page no 220. 
5. Srimadvaidyashodala, Gadanigraha truthiya shalakyadi panchakarmadhikarantho bhagha, Mukharoga adhyaya 5/ 150-152, Chaukambarasamskruthasamsthana. Varanasi; 1990.page no22

\section{Source of Support: Nil}

\section{Conflict of Interest: None Declared}

How to cite this URL: Chaya. C: A Longitudinal Observational Study On The Effect Of Gaurasarsapa Lepana And Lakshadi Taila Gandusha In Diabetic Periodontitis. International Ayurvedic Medical Journal \{online\} 2021 \{cited August 2021\} Available from: http://www.iamj.in/posts/images/upload/1629_1636.pdf 